DOI: $10.20472 / E S .2020 .9 .2 .002$

\title{
TAXPAYER'S BEHAVIOR IN THE CHANGING TAX POLICY
}

\section{EGIDIJUS BIKAS, ROLANDAS SAKALAUSKAS}

\begin{abstract}
:
The aim of the article is to identify the factors determining the taxpayer's behavior, to evaluate Lithuanian taxpayer's behavior by changing tax policy of VAT. The article investigates whether the increase of VAT burden in Lithuania has a significant impact on taxpayer's behavior, encouraging them to voluntarily pay taxes or avoid tax liabilities. The research period is from Q1 2000 - Q4 2016. The study uses VAT gap data. Research methods: correlation analysis, vector auto regression (VAR) model. The use of correlation analysis allows to establish the relationship between tax rates and changes in taxpayer's behavior, while the vector auto regressive method allows to investigate taxpayer's behavioral responses to the changes of tax rate. According to the responses of the impulse functions, the response of taxpayer's behavior (tax avoidance) to the changes in tax policy is determined. The investigation showed, that in the short term, the increased tax burden may lead to decrease of VAT gap, in the medium term an increase in tax burden on VAT may increase the level of tax avoidance in the country.
\end{abstract}

\section{Keywords:}

Taxation, tax behavioral, tax avoidance

JEL Classification: $\mathrm{G} 39, \mathrm{H} 20, \mathrm{H} 26$

\section{Authors:}

EGIDIJUS BIKAS, Vilnius University, Lithuania, Email: egidijusvIn@gmail.com

ROLANDAS SAKALAUSKAS, Vilnius University, Lithuania, Email: rol.sakalauskas@gmail.com

\section{Citation:}

EGIDIJUS BIKAS, ROLANDAS SAKALAUSKAS (2020). Taxpayer's Behavior in the Changing Tax Policy. International Journal of Economic Sciences, Vol. IX(2), pp. 23-38., 10.20472/ES.2020.9.2.002 


\section{Introduction}

Each country must manage its financial resources effectively in order to ensure the social and economic well-being of its citizens. The national budget - the state financial plan according to which the state, executing its fiscal policy measures, generates revenue and distributes financial resources in order to ensure the performance of the necessary state functions and sustainable and consistent development of the state economy.

In order to manage public financial resources efficiently and to ensure the necessary and sufficient quality of public service provision, the behavior of taxpayers becomes a particularly important subject of research, since the collection of state tax revenue directly depends on the behavior of taxpayers. The behavior of taxpayers is strongly dependent on many factors which determine the taxpayer's voluntary payment or refusal to pay taxes. From a traditional, neoclassical point of view, tax avoidance is based on the rational choice of taxpayers and/or maximizing benefits. Taxpayers are homogeneous and behave rationally on the basis of money maximization and selfishness. A taxpayer can choose honestly to declare all income and pay all taxes or avoid tax payments without declaring any revenue. Foreign theorists pay considerable attention to investigate the behavior of taxpayers, but research on the behavior of Lithuanian taxpayers is extremely rare. This implies the need for these studies.

The aim of the article - to assess the impact of changes in the Lithuanian VAT burden on taxpayer's behavior.

VAT is chosen because the tax has the highest fiscal value in the state budget, and on the other hand, the tax decisions related to the application of this tax have a significant impact on the collection of the state revenue. Studies by various foreign authors suggest that tax policy measures and their changes can have different effects on taxpayer's behavior. Most authors agree that the application of restrictive fiscal policy measures in the field of revenue, which occurs because fiscal policy makers raise tax rates, directly affects taxpayer's behavior. There is a growing reluctance to pay taxes, which increases the extent of tax avoidance in the state. Some authors argue that raising tax rates does not adversely affect tax compliance or may even encourage taxpayers to pay all their taxes. Tax avoidance is a particularly significant problem, as it reduces the effectiveness of fiscal policies in the area of revenue.

The author's disagreements indicate the relevance and importance of the topic, so in order to ensure efficient collection of state revenue, it is appropriate to analyze the impact of changes in tax policy on the behavior of Lithuanian taxpayers and the factors influencing taxpayer's behavior.

\section{Literature analysis of the impact of tax policy changes on taxpayer's behaviour}

As the literature indicates the most frequently discussed measure of tax policy and its effect on taxpayer's behavior - changes in tax rates to determine the effect of changed tax rates on the fulfillment or avoidance of tax obligations.

Most theoretical models claim that increasing tax rates increase the size of tax avoidance by taxpayers, but studies do not show unambiguously that increasing tax rates always lead to increase of tax avoidance (Table 1.). 
Table 1. Studies on the impact of tax policy changes on taxpayer's behavior

\begin{tabular}{|c|c|c|c|}
\hline Author & Research object & Research method & Result \\
\hline Clotfelter C. (1969) & $\begin{array}{l}\text { The effect of marginal } \\
\text { tax rate changes on } \\
\text { tax avoidance }\end{array}$ & $\begin{array}{l}\text { Econometric } \\
\text { analysis of elasticity }\end{array}$ & $\begin{array}{l}\text { Rising marginal tax rates } \\
\text { increase tax avoidance }\end{array}$ \\
\hline $\begin{array}{l}\text { Nourzad, } \quad \text { Crane } \\
\text { (1985) }\end{array}$ & $\begin{array}{l}\text { Tax avoidance } \\
\text { responses to tax } \\
\text { increases }\end{array}$ & Model A-S & Positive contact \\
\hline $\begin{array}{l}\text { Pommerehme W., } \\
\text { Weck-Hannemann } \\
\text { H. (1996) }\end{array}$ & $\begin{array}{l}\text { Influence of raising } \\
\text { marginal tax rates on } \\
\text { tax avoidance }\end{array}$ & Regression analysis & $\begin{array}{l}\text { The relationship between } \\
\text { marginal tax rates and tax } \\
\text { avoidance is positive and } \\
\text { statistically significant }\end{array}$ \\
\hline $\begin{array}{l}\text { Abdulsalam M. et } \\
\text { al. (2014) }\end{array}$ & $\begin{array}{l}\text { The impact of tax } \\
\text { rates on tax } \\
\text { compliance using } \\
\text { cross-border data }\end{array}$ & Correlation analysis & $\begin{array}{l}\text { Higher tax rates negatively } \\
\text { impact tax compliance and } \\
\text { increase tax avoidance }\end{array}$ \\
\hline $\begin{array}{l}\text { Elizabeth N. D. et } \\
\text { al. (2015) }\end{array}$ & $\begin{array}{l}\text { Impact of income tax } \\
\text { rate increase on tax } \\
\text { avoidance among } \\
\text { business owners }\end{array}$ & Correlation analysis & $\begin{array}{l}\text { As tax rates rise, business } \\
\text { owners are less willing to } \\
\text { pay taxes voluntarily }\end{array}$ \\
\hline $\begin{array}{l}\text { Adebisi J.F., Gbegi } \\
\text { D.O. (2013) }\end{array}$ & $\begin{array}{l}\text { Impact of personal } \\
\text { income tax change on } \\
\text { taxpayer behavior }\end{array}$ & $\begin{array}{l}\text { Variance (ANOVA) } \\
\text { analysis }\end{array}$ & $\begin{array}{l}\text { There is a positive link } \\
\text { between rising tax rates } \\
\text { and increasing tax } \\
\text { avoidance }\end{array}$ \\
\hline $\begin{array}{l}\text { Chiarini B. et al. } \\
(2011)\end{array}$ & $\begin{array}{l}\text { The long-term } \\
\text { relationship between } \\
\text { the VAT burden and } \\
\text { tax avoidance }\end{array}$ & $\begin{array}{l}\text { Vector } \\
\text { autoregression } \\
\text { (VAR) model }\end{array}$ & $\begin{array}{l}\text { Positive link between rising } \\
\text { effective VAT rates and } \\
\text { long-term tax avoidance }\end{array}$ \\
\hline $\begin{array}{lll}\text { Gashi, } & \text { Kukaj } & \text { H. } \\
(2016) & & \end{array}$ & $\begin{array}{l}\text { Factors influencing } \\
\text { taxpayer's behavior }\end{array}$ & Survey & $\begin{array}{l}\text { Changes in fiscal policy is } \\
\text { one of the key factors } \\
\text { affecting taxpayer's } \\
\text { behavior }\end{array}$ \\
\hline Slemrod J. (1985) & $\begin{array}{l}\text { The relationship } \\
\text { between tax } \\
\text { avoidance and tax } \\
\text { rates }\end{array}$ & Correlation analysis & $\begin{array}{l}\text { There was no statistically } \\
\text { significant dependency } \\
\text { between rising tax rates } \\
\text { and tax avoidance }\end{array}$ \\
\hline
\end{tabular}




\begin{tabular}{|l|l|l|l|}
\hline $\begin{array}{l}\text { Modugu P.K. et al. } \\
(2012)\end{array}$ & $\begin{array}{l}\text { Impact of tax rates on } \\
\text { the voluntary } \\
\text { fulfillment of tax } \\
\text { obligations }\end{array}$ & $\begin{array}{l}\text { Statistical } \\
\text { significance tests } \\
\text { using survey data }\end{array}$ & $\begin{array}{l}\text { They found no statistically } \\
\text { significant dependence on } \\
\text { tax rates and voluntary } \\
\text { fulfillment of tax obligations }\end{array}$ \\
\hline $\begin{array}{l}\text { Beck P.J. et al. } \\
(1991)\end{array}$ & $\begin{array}{l}\text { The impact of tax } \\
\text { rates and other } \\
\text { variables on tax } \\
\text { avoidance }\end{array}$ & $\begin{array}{l}\text { Analysis of } \\
\text { laboratory } \\
\text { experiment data by } \\
\text { ANOVA }\end{array}$ & $\begin{array}{l}\text { Higher tax rates reduce tax } \\
\text { avoidance }\end{array}$ \\
\hline
\end{tabular}

Source: Created by authors

Many studies confirm that restrictive fiscal policies on income are positively correlated with tax avoidance. One of the first studies to analyze the impact of tax rates on tax avoidance was conducted by C. Clotfelter using a sample of 47,000 taxpayers in 1969 (Freine-Seren and Panades, 2013). Research has shown that higher marginal tax rates have a significant impact on tax avoidance. The author concludes that higher tax rates reduce tax compliance in three different taxpayer groups having different incomes. The estimated elasticities of the different taxpayers ranged from 0,501 to 0,844 . This means that, on average, reducing the marginal tax rate by 10 percent tax avoidance decreased by 5-8 percent (Freine-Seren et al., 2013).

According to R.J.Bakija (2011), when tax rates rise, taxpayers tend to declare lower income and thus avoid paying part of the tax. W. Pomnerehme and H. Weck-Hannemann (1996) studied data in Switzerland in order to determine taxpayer's behavioral responses to changes in tax rates. For independent variables, the authors chose average marginal tax rates (because the Swiss tax system is progressive), audit probability, and other indicators. The results of the author's regression analysis showed that the relationship between marginal tax rates and tax avoidance is positive and statistically significant. According to R. Fisman and W. Shang-Jim (2001) one p.p. (p.p. - percentage point) tax rate increases lead to three p.p. increase in tax avoidance. Chiarini, E. Marzano, and Schneider (2011), studying the long-term effects of the value added tax burden on tax avoidance in Italy identified that the value added tax and its effective tax rate is one of the factors influencing the long-term magnitude of tax avoidance in the state. Fiscal policymakers, therefore, have a particular responsibility to conduct fiscal policy measures properly and VAR models and their research must become a particularly relevant tool for fiscal policymakers to conduct fiscal policies which are consistent and responsive to tax sustainability in order to ensure sustainable economic development of the state.

While most authors have found out that tax rates increase with tax avoidance, some studies have shown that increasing tax rates have no relation to increasing tax avoidance, or that they have even the opposite dependence, i.e. rising tax rates lead to declining tax avoidance. J. Slemrod (1985) found no statistically significant relationship between rising tax rates and tax avoidance in 1977 US investigations relationship between tax avoidance and variables such as tax rates, real income, age, and marital status. Meanwhile, Alm. et al. (1995), P. J. Beck (1991) found the opposite dependence between rising tax rates and tax avoidance. The relationship between tax rates and tax avoidance has not been shown in studies by Modugu et al., (2012). 
Summarizing the analysis of scientific literature, it is not possible to conclude unambiguously what the impact of tax policy is on taxpayer's behavior. While most authors argue that the increase of tax rates, tax avoidance rates in the country go up, while some studies have shown no correlation between these variables, while various studies have shown that tax rates may even increase tax compliance.

\section{Lithuanian VAT tax payer's behavioral research methodology}

In order to ensure efficient collection of state revenue and long-term development of the state's economic growth, it is necessary to examine in detail the impact of changes in Lithuanian tax policy on the behavior of Lithuanian taxpayers. VAT is based on two elements: the fiscal tax value is the highest in the state budget and viewed via the prism of fiscal multipliers; it is a tax on the increase of tariffs which has one of the lowest values of fiscal multipliers and the least negative impact on the state economy.

Research methods: correlation analysis, vector autoregression (VAR) method. The correlation analysis method aims to determine the relationship between tax rates and changes in taxpayer's behavior, while the vector autoregressive method allows to assess taxpayer's responses to changes in fiscal policy in the sphere of income.

Correlation analysis is performed on the basis of the Pearson correlation coefficient, whose overall expression is (formula (1)) (Martišius, Kèdaitis, 2013):

$$
r=\frac{\sum(x-x)(y-\eta)}{\sqrt{\left[\sum(x-x)^{2}\right]\left[\sum(y-\not)^{2}\right]}}
$$

where: $r=$ correlation coefficient of sample

$\mathrm{x}=$ the value of one variable.

$y=$ the value of the next variable.

Pearson's correlation coefficient is calculated as the product of two pairs of values, where each value is subtracted from the meaning and divided by the product of standard deviations (Martišius, Kèdaitis, 2013).

The vector autoregression (VAR) model is constructed by its general expression and calculated using formula (2):

$$
Z_{\mathrm{t}}=A_{0}+\sum_{\mathrm{i}=1}^{p} A_{\mathrm{i}} Z_{\mathrm{t}-\mathrm{i}}+e_{\mathrm{t}}: p>0
$$

where: $Z_{t}-$ is the vector for the measurement of endogenous variables $n$;

$A_{0}$ - vector of constant $n$ measurements;

$e_{t}$ - vector of errors;

$A_{i}-n{ }^{*} n$ matrix of measurement coefficients to variables;

$p$ - is the auto regression order. 
The VAR model deals with multidimensional time series and is modeled as a function of a variable depending on its own lags and the values of the lags of other variables. In economic terms, this implies that some changes in the macroeconomic indicators have an impact on other indicators or on themselves after several periods, i.e. the response to impulses is lagged. This lag-based model reflects the reality of the impact of fiscal policy on macroeconomic variables.

In order to achieve the goal, the investigation is divided into stages. The first phase aims to collect the amounts of VAT burden, a sample of the effective data on these rates. Next, the data is systematized and processed to create the necessary data lines for further modeling of the VAR method. At this stage, a retrospective sample of VAT taxpayer's behavior is created. At a later stage, the VAR model is modeled. An Augmented Dickey-Fuller test is performed and the level of integration of each of the model time series is checked. Non-stationary time series are transformed into stationary. Lag line tests are performed using LR, FPE, AIC (Akaike information criterion), HQ (Hannan - Quinn) and SC (Schwarz information criterion) lag line tests to obtain optimum line values. The final expression of the VAR model is constructed and model estimates are obtained. The final VAR model is analyzed applying impulse response function. The impulse response functions obtained can be used to determine the response of taxpayer's behavior (changes in tax avoidance), changes in tax policy.

Investigative sample: $1^{\text {st }}$ quarter of $2000-4^{\text {th }}$ quarter of 2016 . The maximum possible study period is chosen because long time series of data are a prerequisite for the development of a representative VAR model.

Study variables. Changes in taxpayer's behavior: the research uses VAT gap data. The VAT gap is defined as the difference between the total VAT liability (VTTL) and the actual amount collected from VAT. Values for this indicator are calculated annually on a top-down method on the basis of national accounts data and are publicly available by the European Commission. VTTL is calculated using formula (3) (European Commission, 2018):

$$
V T T L=\sum_{\mathrm{i}=1}^{N}\left(r_{\mathrm{i}} \times V_{\mathrm{i}}\right)+\sum_{\mathrm{i}=1}^{W}\left(n_{\mathrm{i}} \times p_{\mathrm{i}} \times I C_{\mathrm{i}}\right)+\sum_{\mathrm{i}=1}^{W}\left(r_{\mathrm{i}} \times p_{\mathrm{i}} \times G F C F_{\mathrm{i}}\right)+n a
$$

where: $\quad r$ - is the effective VAT rate in the country;

$V$ - is the value of final consumption;

IC - is the value of intermediate consumption;

$p$ - is a percentage calculated from the total VAT exempt production;

GFCF - defines the value of final capital formation and index $\mathrm{i}$ indicates the economic sector;

na - net adjustments.

The VAT gap ratios are measured in both nominal and relative terms with VTTL and GDP. The nominal size of the VAT gap in the study is defined as GAP (1), the relative amount with all tax liabilities is defined as GAP (2) and calculated according to formula (4) (European Commission, 2018): 
$\operatorname{GAP}(2)_{t}=\frac{\operatorname{GAP}(1)_{t}}{\operatorname{VTTL_{\mathrm {t}}}}$

The relative VAT gap with GDP is stated as GAP (3) and calculated as the ratio of the nominal VAT gap to the nominal GDP and calculated using formula (5):

$\operatorname{GAP}(3)_{t}=\frac{G A P(1)_{t}}{G D P_{t}}$

Changes in VAT rates. This indicator includes the VAT tax burden, which is calculated by dividing tax revenue by Gross Domestic Product. The processing of data gives nominal and effective indicators of the VAT burden. The nominal measure of the VAT burden is obtained by dividing VAT revenue by nominal GDP (Koncevičienè, Prievelis, 2012). This indicator is stated as TAX (1) in the study and is calculated using formula (6):

$$
\operatorname{TAX}(1)_{\mathrm{t}}=\frac{\operatorname{VAT}_{\mathrm{t}}}{G D P_{\mathrm{t}}}
$$

The effective rate is the VAT revenue divided by the difference between GDP and VTTL (Chiarini, Marzano, Schneider, 2011). This indicator is noted as TAX (2) and is calculated using formula (7):

$$
\operatorname{TAX}(2)_{\mathrm{t}}=\frac{\operatorname{VAT}_{\mathrm{t}}}{G D P_{\mathrm{t}}-V T T L_{\mathrm{t}}}
$$

These indicators are used in the study as indices of changes in tax rates.

\section{Lithuanian VAT payers behavior analysis}

The nominal VAT gap in Lithuania between 2000 and 2013 tended to increase consistently (Figure 1.). The value of this indicator in 2000 was 408 million euros. While in 2013 this figure was already 1642 million euros. Over the 13-year period, the value of the VAT gap has more than tripled, with the annual VAT gap widening to $11.76 \%$.

Figure 1. VAT gap 2000 - 2016. Compiled by authors based on EC data.

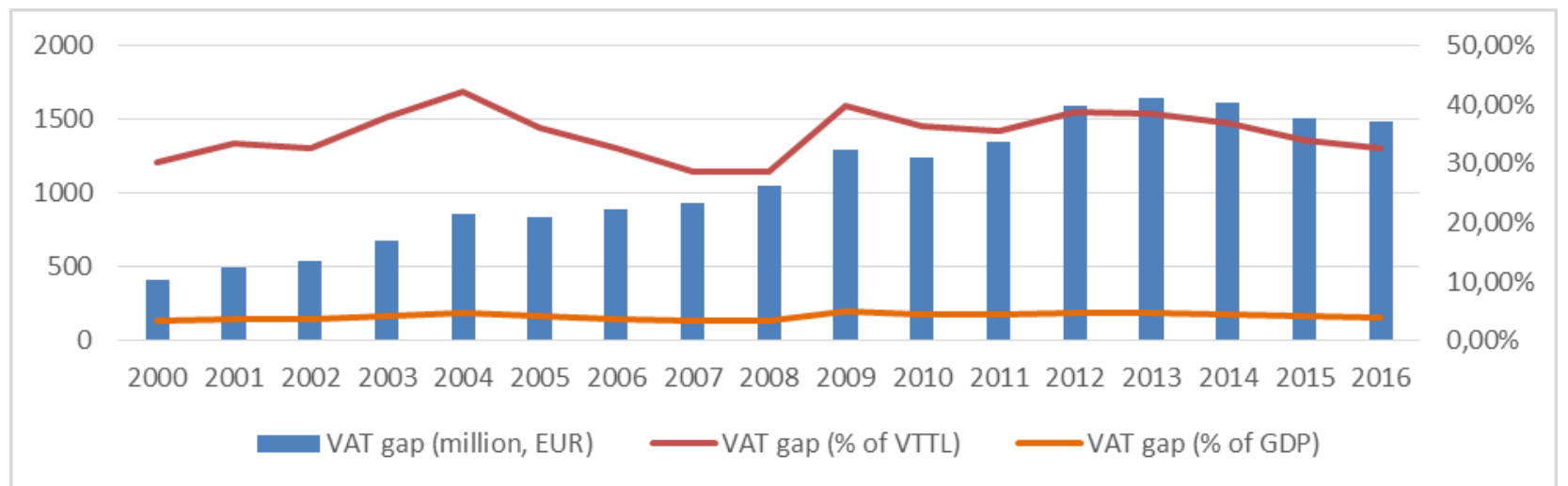

Although the nominal VAT gap widened during this period, the relative size of this indicator with the total VAT liability (VTTL) did not increase throughout the period under review. VAT ratio in comparison with VTTL in 2000 was $30,29 \%$, between the year of 2000 and 2004 this indicator increased on average by 8,84 p.p. annually and in 2004 reached $42,15 \%$ and was the highest 
throughout the period under analysis. In 2005 the figure dropped to $36 \%$ and declined steadily until 2008, when it accounted for $28,78 \%$. In 2009 , during the economic recession, this indicator grew by more than $10 \%$ a year and accounted for 39,81\%. In 2010-2014 the indicator fluctuated between $35,5-38,38 \%$, and from 2012 to 2016 there was a consistent downward trend, with an average of 4,2 p. p. every year.

The relative ratio of the VAT gap to the national GDP was not marked by high fluctuation. Throughout the period analyzed, the relative size of this indicator fluctuated from 3,2-4,90\%. A significant change in this indicator is noticeable only in 2009 , when the value of the indicator compared to 2008 increased from 3,2\% to $4,90 \%$. The significance of the VAT gap indicator, as compared to all VAT tax liabilities, has been steadily decreasing since 2012, when the value of this indicator accounted for $4,77 \%$ but in 2016 the value of this indicator decreased to $3,86 \%$.

Annual data on the VAT gap rate are transformed using the Chow-Lin procedure. Time series estimates are derived using the Eviews 10 statistical analysis package. It is noted that during the Chow-Lin procedure, the investigation period is shortening from $1^{\text {st }}$ quarter of 2000 to $1^{\text {st }}$ quarter of 2016 i.e. by 3 quarters.

Ensuring that all variables are stationary in the model (Table 2.) it is important to construct a suitable model for further construction of the VAR model. The stationarity of the model variables is verified by Augmented Dickey - Fuller (ADF) test. The purpose of this test is to verify that the time series has a unit root. This unit root is a time series autoregression parameter equal to 1 . If the model time series have a unit root, then it is stated that this time series is non-stationary and cannot be applied in the VAR model. The ADF testing procedure is performed for the model using formula (8):

$$
\Delta Y_{t}=\alpha+\beta t+\gamma Y_{t-1}+\delta_{1} \Delta Y_{t-1}+\ldots+\delta_{p} \Delta Y_{t-p}+\varepsilon_{t}
$$

Where: $\alpha$ and $\beta$ are constants, $\mathrm{p}$ is the number of delays. The unit root test is run on the zero hypothesis:

$H_{0}$ : The process $X_{\mathrm{t}}$ has a unit root

If the zero hypothesis is rejected, an alternative hypothesis is accepted:

$H_{\mathbb{a}}$ : Process $X_{\mathrm{t}}$ is stationary.

The results obtained show that applying the ADF test to both the VAT burden (nominal) and VAT burden (effective) time series do not rule out the zero hypothesis that time series have a unit root. Both of these time series are differentiated according to the first order and are re-subjected to the ADF stationarity test.

\section{Table 2. ADF stationarity test results}

\begin{tabular}{|l|l|l|}
\hline Variable t statistic & t statistic & p value \\
\hline TAX(1) & $-2,25$ & 0,1912 \\
\hline TAX(1) 1st order diff. & $-3,57$ & $0,0092^{*}$ \\
\hline
\end{tabular}




\begin{tabular}{|l|l|l|}
\hline TAX(2) & $-1,73$ & 0,4114 \\
\hline TAX(2) 1st order diff. & $-4,23$ & $0,0013^{\star}$ \\
\hline GAP(1) & $-2,02$ & 0,2782 \\
\hline GAP(1) 1st order diff. & $-2,63$ & $0,0924^{\star \star \star}$ \\
\hline GAP(2) & $-2,91$ & $0,0485^{\star \star}$ \\
\hline GAP(3) 1 st order diff. & $-2,79$ & $0,0661^{\star \star \star}$ \\
\hline GAP(3) & $-3,56$ & $0,0106^{\star}$ \\
\hline
\end{tabular}

Critical values for the ADF stationarity test are: $3.54(1 \%), 2.91(5 \%), 2.59(10 \%) .{ }^{*} p$ value $<0.01 ;{ }^{* *}$ with $p$ value $<0.05 ;{ }^{* * *} p$ value $<0.1$

The results indicate that in the first-order differentiation of the time series, 99 percent in the confidence interval the zero hypothesis is rejected and the alternative hypothesis is accepted.

While estimating the stationarity of the VAT gap time series with the ADF test, we cannot reject the zero hypotheses that the VAT gap (million euros) time series has a unit root, so this time series is also differentiable in the first line series. The zero hypotheses is rejected in $90 \%$ of the changes in the confidence interval and the alternative hypothesis is accepted if time series stationary. The ADF test shows that the percentage of the VAT gap of all liabilities, the t-statistical significance is greater than $5 \%$ of the critical value and the zero hypothesis is rejected. VAT gap percentage from the GDP time series t-statistical value is greater than the critical value of $90 \%$ in the confidence interval. However, for higher model representativeness the time series are differentiated by first line. After making changes to the time series, a repeated ADF stationarity test is performed with a t-statistic value $(-3,56)$ which is greater than the critical value of $99 \%$ therefore in confidence interval the zero hypothesis is rejected and an alternative hypothesis is accepted (the time series is stationary).

Time series stationarity tests have reduced the study period by one quarter from $1^{\text {st }}$ quarter of 2000 to $1^{\text {st }}$ quarter of 2016 shortening to $2^{\text {nd }}$ quarter of 2000 to $1^{\text {st }}$ quarter of 2016 . The tests to determine the lag of the statistical model continue.

The next step in establishing an efficient VAR model is to identify proper lag periods. Different tests can be used to determine the appropriate number of lags. In this study, LR, FPE, AIC (Akaike information criterion), and HQ (Hannan - Quinn) tests are performed (Table 3.), and the recommended lag sequences obtained from the following model lag tests are presented. All lag order tests recommended to include two period (quarter) lag in VAR models. The only VAR model under construction for which lag order tests did not show unambiguous results was the VAT burden percentage (nominal) and VAT gap (million euros) model for vector autoregression. For model under construct, the LR, SC, and $\mathrm{HQ}$ lag order termination tests recommended the inclusion of a two-period lag order, whereas the FPE and AIC models recommend the inclusion of three-period delays. Given that more test queuing results are recommended to include two period lags, it is decided to include two period lags in this final VAR model.

Table 3. Lag order test results

\begin{tabular}{|l|l|l|l|l|l|l|}
\hline VAR Model Variables & $\begin{array}{l}\text { The optimal lag } \\
\text { order }\end{array}$ & LR & FPE & AIC & SC & HQ \\
\hline $\operatorname{TAX}(1)$ and GAP(1) & II & II & III & III & II & II \\
\hline
\end{tabular}




\begin{tabular}{|l|l|l|l|l|l|l|}
\hline $\operatorname{TAX}(1)$ and GAP(2) & II & II & II & II & II & II \\
\hline $\operatorname{TAX}(1)$ and GAP(3) & II & II & II & II & II & II \\
\hline $\operatorname{TAX}(2)$ and GAP(1) & II & II & II & II & II & II \\
\hline $\operatorname{TAX}(2)$ and GAP(2) & II & II & II & II & II & II \\
\hline $\operatorname{TAX}(2)$ and GAP(3) & II & II & II & II & II & II
\end{tabular}

Summarizing the results of the lag sequence tests, all final VAR models include lag of two periods (quarters). Following the systematization and processing of all study data and the construction of the final model, the most important research results are presented below.

In the process of analysis, 6 VAR models were developed to measure how changes in tax rates, which are defined as estimates of the nominal and effective burden of VAT, affect taxpayer's behavior, which is expressed through the VAT gap. Estimates of the final 6 VAR models are presented in Table 4. The coefficients of determination $\left(R^{2}\right)$ of the constructed models show the proportion of the dependent variable which is explained by the independent variables. The table above shows that changes in the VAT gap (EUR million) can be explained by $66 \%$ of factors which are included in the VAR model (nominal and effective VAT tax burden rates and the VAT gap lag functions themselves). The highest coefficients of determination are found in the $V_{A} R_{2}$ and $V_{A R}$ models, which are expressed as functions where the percentage of the VAT gap from all VAT liabilities in response to changes in tax burden rates is modeled. Correspondingly, the coefficients of determination for these VAR models are equal to 0.96 . The lowest coefficients of determination according to the model are characterized by $V A R_{a}$ ir $V A R_{6}$ models, both of which have values of 0.46 and 0.47 respectively.

Table 4. Results of VAR models

\begin{tabular}{|c|c|c|c|c|}
\hline $\begin{array}{l}\text { VAR } \\
\text { mode } \\
\text { I } \\
\text { name }\end{array}$ & Model Description & $\begin{array}{l}\text { Abbreviatio } \\
\text { ns in model } \\
\text { expression }\end{array}$ & Model expression & $\left(R^{2}\right)$ \\
\hline$V A R_{1}$ & $\begin{array}{l}\text { The response of the VAT } \\
\text { gap (million EUR) to the } \\
\text { impulse changes in the } \\
\text { nominal VAT burden. }\end{array}$ & $\begin{array}{l}\text { GAP } \mathbf{( 1 )}- \\
\text { VAT gap } \\
\text { million euros }\end{array}$ & $\begin{array}{l}G A P(1)_{t}=0,0032-0,2306 * \operatorname{TAX}(1)_{t-1} \\
+0,9453 * \operatorname{TAX}(1)_{t-2}+0,88 * G A P(1)_{t-1} \\
-0,0803^{*} G A P(1)_{t-2}\end{array}$ & 0,66 \\
\hline$V A R_{2}$ & $\begin{array}{l}\text { The response of the VAT } \\
\text { gap (as a percentage of } \\
\text { total liabilities) to the } \\
\text { impulse changes in the } \\
\text { nominal VAT burden. }\end{array}$ & $\begin{array}{l}\text { GAP }(2)- \\
\text { VAT gap }(\% \\
\text { of total } \\
\text { liabilities) }\end{array}$ & $\begin{array}{l}G A P(2)_{t}=0,0388-0,7782 * T A X(1)_{t-1^{-}} \\
0,9689 * T A X(1)_{t-2}+ \\
1,4482 * G A P(2)_{t-1}-0,5581^{*} G A P(2)_{t-2}\end{array}$ & 0,94 \\
\hline$V A R_{a}$ & $\begin{array}{l}\text { The response of the VAT } \\
\text { gap (as a percentage of } \\
\text { GDP) to the impulse }\end{array}$ & $\begin{array}{l}\text { GAP }(3) \quad- \\
\text { VAT gap }(\%\end{array}$ & $\begin{array}{l}G A P(3)_{t}=1,73 E-05-0,106 * \operatorname{TAX}(1)_{t-1} \\
-0,0310 * \operatorname{TAX}(1)_{t-2}+0,668 * \operatorname{GAP}(3)_{t-1}\end{array}$ & 0,46 \\
\hline
\end{tabular}




\begin{tabular}{|c|c|c|c|c|}
\hline & $\begin{array}{l}\text { changes in the nominal } \\
\text { VAT burden. }\end{array}$ & of GDP) & $-0,122^{*} G A P(3)_{t-2}$ & \\
\hline$V A R_{4}$ & $\begin{array}{l}\text { The response of the VAT } \\
\text { gap (million EUR) to the } \\
\text { impulse changes in the } \\
\text { effective VAT rate. }\end{array}$ & $\begin{array}{l}\text { Rate of the } \\
\text { nominal VAT } \\
\text { burden }\end{array}$ & $\begin{array}{l}G A P(1)_{t}=0,0038-0,7804 * \operatorname{TAX}(2)_{t-1} \\
+0,4883 * \operatorname{TAX}(2)_{t-2}+ \\
0,8835 * G A P(1)_{t-1}-0,1097^{*} G A P(1)_{t-2}\end{array}$ & 0,66 \\
\hline$V A R_{5}$ & $\begin{array}{l}\text { The response of the VAT } \\
\text { gap (as a percentage of } \\
\text { total liabilities) to the } \\
\text { impulse changes in the } \\
\text { effective VAT burden. }\end{array}$ & $\begin{array}{l}\text { TAX(2) - } \\
\text { Effective VAT } \\
\text { burden rate }\end{array}$ & $\begin{array}{l}G A P(2)_{t}=0,03534-0,5983 * T A X(2)_{t-1} \\
-0,7202 * \operatorname{TAX}(2)_{t-2}+ \\
1,5073 * \operatorname{GAP}(2)_{t-1}-0,6073^{*} \operatorname{GAP}(2)_{t-2}\end{array}$ & 0,94 \\
\hline $\operatorname{VAR}_{6}$ & $\begin{array}{l}\text { The response of the VAT } \\
\text { gap (as a percentage of } \\
\text { GDP) to the impulse } \\
\text { changes in the effective } \\
\text { VAT burden. }\end{array}$ & & $\begin{array}{l}G A P(3)_{t}=2,04 E--0,0874 * \operatorname{TAX}(2)_{t-1} \\
-0,034 * \operatorname{TAX}(2)_{t-2}+0,6794 * \operatorname{GAP}(3)_{t-1} \\
-0,0945^{*} \operatorname{GAP}(2)_{t-2}\end{array}$ & 0,47 \\
\hline
\end{tabular}

In order to identify the relationship between the two variables, Pearson's correlation coefficients are presented (Table 5.).

Table 5. Results of correlation analysis

\begin{tabular}{|l|l|l|l|l|l|}
\hline & TAX(1) & TAX(2) & GAP(1) & (GAP2) & (GAP3) \\
\hline TAX(1) & $\mathbf{1}$ & 0,9079 & 0,3407 & $-0,6182$ & $-0,4829$ \\
\hline TAX(2) & 0,9079 & $\mathbf{1}$ & 0,6067 & $-0,2573$ & $-0,2593$ \\
\hline GAP(1) & 0,3407 & 0,6067 & $\mathbf{1}$ & 0,3276 & 0,6069 \\
\hline (GAP2) & $-0,6182$ & $-0,2573$ & 0,3276 & $\mathbf{1}$ & 0,9250 \\
\hline (GAP3) & $-0,4829$ & $-0,2593$ & 0,6069 & 0,9250 & $\mathbf{1}$ \\
\hline
\end{tabular}

In evaluating the results obtained, it should be noted that the correlation coefficient value between the nominal value of the VAT burden and the VAT gap in million euros equals to 0,3407 . This indicator implies that the relationship between these variables is weak. Nevertheless, it is important to note that the correlation coefficient between the effective VAT burden rate and the VAT gap (million EUR) is 0,6067 , which indicates that there is an average correlation between these variables. The value of this indicator is positive, which shows that both indicators are changing in the same direction.

Analyzing the relative size of the nominal VAT burden and the VAT gap with all tax liabilities, it is observed that the value of the Pearson correlation coefficient between these variables is $-0,6182$ and it is negative. There is an average inverse of these two variables, and the variables move in opposite directions. It is noted that the correlation of the effective rate with the relative size of the 
VAT gap with all liabilities is smaller than the nominal and it is $-0,2573$, which indicates that there exists a weak relationship between two variables. Based on the results obtained, the value of the correlation coefficient between the nominal value of the VAT burden and the relative size of the VAT gap as a percentage of GDP is $-0,4829$. It indicates that there is an average inverse relationship between these two variables. Despite the fact that the nominal burden of the VAT and the VAT gap percentage a moderate correlation with GDP exists and it is important to mention that the effective VAT burden ratio and the VAT gap percentage from GDP the statistical correlation is weak and stands at $-0,2593$.

From the results of the correlation analysis, it cannot be unequivocally concluded that there is a strong statistical relationship between tax rates and taxpayer's behavior. The results obtained suggest that only a weak or moderate statistical relationship exists between these variables. These results also confirm the results of some foreign authors' studies, which do not seem to have a strong statistical correlation.

Because taxpayers' response to changes in tax policy may have a delayed and immediate effect, further investigation of VAR models identifies delayed potential effects. The impulse response functions are applied for this purpose. The response of the VAT gap to changes in the nominal VAT rate by including two time series (quarterly) lag order is presented in Figure $2 .$.

Figure 2. Response of the VAT gap to changes in the nominal VAT burden a) VAT gap million euros (b) VAT gap percentage response to total liabilities c) percentage of VAT gap response to GDP. (Prepared by the authors on the basic of results processed)

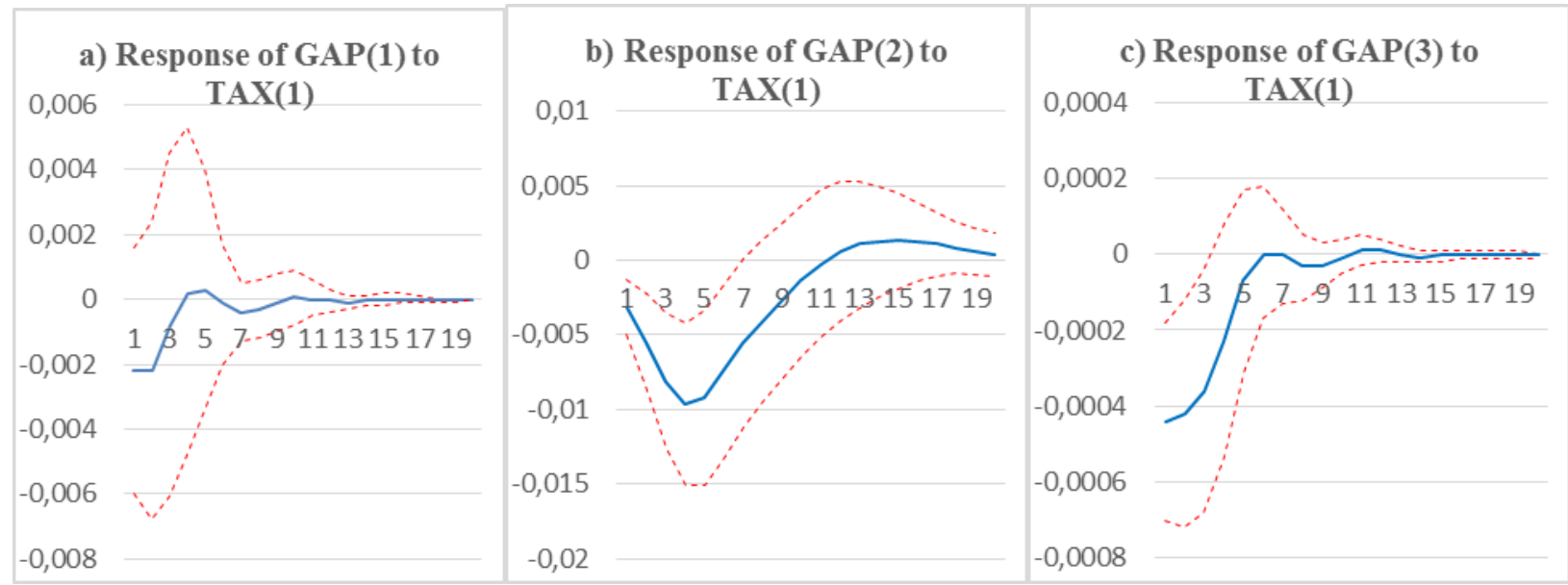

For the purposes of a detailed study, the VAT gap is assessed both on the basis of its nominal amounts (million euros) and on the basis of its relative tax liability and GDP. The data needed for the impulse response analysis were obtained using the Eviews 10 impulse response function (IRF). Cholesky's order factor is a necessary step to plot impulse response graphs. A decision on the order of the fiscal variables is needed to identify taxpayers' responses to fiscal policy measures. These restrictions provide the basis for policy decisions, in other words, what happens first: changes in tax rates or changes in the VAT gap. Given the specific nature of the scientific issue under investigation, and in order to evaluate the response of taxpayers to changes in tax 
rates, and not vice versa, changes in the VAT burden rates are the first member of Cholesky's rank.

All taxpayer's behavioral responses, both in terms of VAT gap figures in millions of euros and in relative percentages of total liabilities and GDP, are minimal (Fig. 2.). It has been observed that the increase in the nominal VAT tax burden even reduces the VAT gap by $0,25 \%$ during the first two quarters. However, after four quarters of the impulse, taxpayers' behavior reverses and the tax gap widens by 0,03 percent. The results show that the shock caused by the increase in the VAT burden after 6 periods completely disappears. Evaluating the relative sizes of the VAT gap responses, they are also relatively small, with $1 \%$ increase in the nominal burden of VAT which has a particularly small impact on the VAT gap of $0,1 \%$ after 4 periods, when it reaches its peak and begins to decline.

Looking at the long-term impact of changes in the VAT burden on taxpayers' behavior, it can be concluded that it is insignificant. The response evoked by all analyzed impulses tends to decrease after 4-6 periods and approach zero completely. It indicates, that there is no long-term significant relationship between the VAT burden rates and the VAT gap.

The analysis of the VAT gap response to changes in the effective VAT burden shows that the results obtained are similar to those of the impulse changes in the VAT gap response to the nominal VAT burden (Figure 3.).

Figure 3. The VAT gap response to effective changes in the VAT burden rate. a) VAT gap million EUR (b) VAT gap percentage response to total liabilities c) percentage of VAT gap response to GDP.

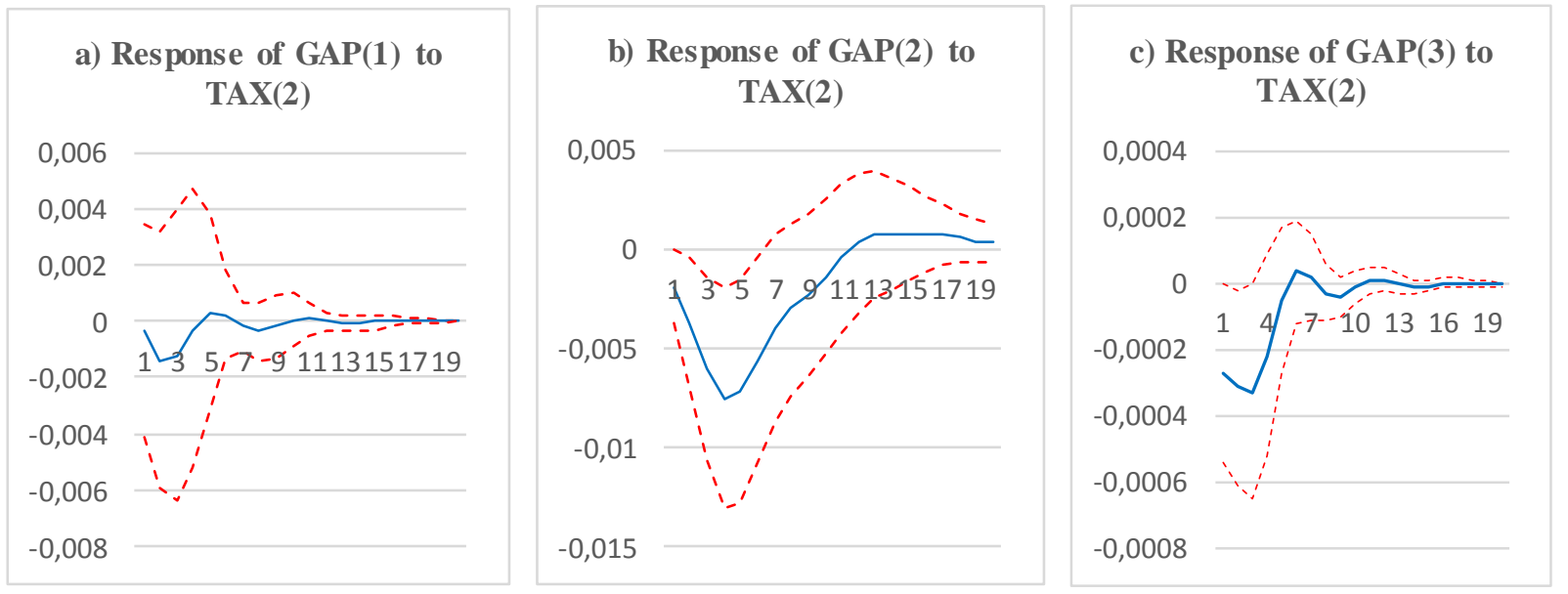

The results show that $1 \%$ increase in the effective burden of VAT, the nominal value of VAT gap is reduced by $0,14 \%$ after two periods when it reaches its peak and begins to decline. After 5 periods, the response to the impulse is already positive, reaching $0,03 \%$ which means that the increased tax burden has a small impact on the widening of VAT gap. After 6 periods, the pulse decreases to zero and persists in the long term. The greatest impact of the effective change in the VAT burden is seen in the analysis of the relative size of VAT gap compared to all tax liabilities, which has a decreasing response to the positive change in the VAT burden for the first 4 periods, 
after which this effect begins to decline and approaches zero. It is worth noticing that after 12 periods this response is already positive, and in due time finally disappears. The shock caused by the effective size of the VAT burden has the smallest impact on the relative size of the VAT gap relative to GDP. Increase of $1 \%$ the VAT burden rate is only $0,04 \%$ the impact of this VAT gap in the first 3 quarters is negative and after 6 periods it is already causing a small increase in the VAT gap. After 10 periods, this response completely disappears. Looking at the long-term impact of the VAT-effective rate shock on the VAT gap, its tendency to disappear completely within the first 10 periods and the long-term impact is negligible.

\section{Discussion of results}

Based on the results of vector autoregression (VAR) models, it can be stated that there is a minor impact of tax shocks on taxpayer's behavior in the short term. The results show that in the short term, the increased tax burden may lead to decrease of VAT gap. Even though these results contradicts with majority of results found in similar studies (Clotfelter C. (1969); Nourzad, Crane (1985); Pommerehme W., Weck-Hannemann H. (1996); Abdulsalam M. et al. (2014); Elizabeth N. D. et al. (2015); Adebisi J.F., Gbegi D.O. (2013); Chiarini B. et al. (2011)), these results confirm the assumptions of the early neoclassical model and results of the studies performed by Beck P.J. et al. (1991).

Results show that in the medium term, the impact of shocks caused by an increase in the VAT burden on taxpayer's behavior is decreasing and moving in the opposite direction, i.e. an increase in the tax burden on VAT in the medium term may increase the level of tax avoidance in the country. These results confirm the findings of similar studies that have been done by most of other authors (Clotfelter C. (1969); Nourzad, Crane (1985; Pommerehme W., Weck-Hannemann H. (1996); Abdulsalam M. et al. (2014); Elizabeth N. D. et al. (2015); Adebisi J.F., Gbegi D.O. (2013) and Chiarini B. et al. (2011)) but it is important to note that the medium-term effects are relatively small.

While the impact of tax shocks on taxpayer's behavior in the short and medium term is relatively small and increase in tax burden could affect fluctuations of VAT gap in both directions, VAR model results show that in the long term this effect returns to equilibrium and disappears completely and these findings are similar to studies that have been done Slemrod J. (1985) and Modugu P.K. et al. (2012). These results suggest that the contradictions in the results that have been observed in similar studies might be strongly affected by the period of observation as the actual response of taxpayer's behavior in the changing tax policy might differ in the short, medium and long terms.

\section{Conclusions}

The research did not show unambiguous results, which prove that increasing VAT tax burden increases the extent of tax avoidance in Lithuania. Correlation analysis showed that although there is a moderate statistical relationship between increasing VAT burden in Lithuania and nominal VAT gap, the relative VAT gap ratios indicate that this correlation is weak and the correlation coefficient is negative, i.e. that the size of VAT burden and the VAT gap is moving in opposite directions. Based on the results of vector autoregression (VAR) models, it should be 
stated that there is a minor impact of tax shocks on taxpayer's behavior in the short term. The results show that in the short term, the increased tax burden may lead to decrease of VAT gap, which confirms the assumptions of the early neoclassical model. In the medium term, the impact of shocks caused by an increase in the VAT burden on taxpayer's behavior is decreasing and moving in the opposite direction, i.e. an increase in the tax burden on VAT in the medium term may increase the level of tax avoidance in the country. These results confirm the findings of most foreign authors, but it is important to note that the medium-term effects are relatively small. While there is a relatively small impact of tax shocks on taxpayer's behavior in the short and medium term, in the long term this effect returns to equilibrium and disappears completely. Therefore, it cannot be concluded that in the long term the increasing VAT burden has a significant impact on the changes in the behavior of taxpayers in Lithuania.

The results of the survey suggest that with the increase of tax burden, Lithuanian taxpayers are not inclined to increase the size of tax avoidance. This suggests that fiscal policymakers planning to increase the tax burden through restrictive fiscal policies would not be likely to face adverse taxpayer's responses, which would lead to strong tax avoidance.

\section{REFERENCES}

Abdulsalam, M., Almustapha, A., El-Maude, J. G. (2014). Tax rate and tax compliace in Africa. European Journal of Accounting Auditing and Finance Research, Vol.2, No. 3, pp. 22-30, May 2014.

Adebisi, J. F., Gbegi, D. O. (2013). Effect of Tax Avoidance and Tax Evasion on Personale Income Tax Administration in Nigeri. American Journal of Humanities and Social Science, Vol 1, N0.3, pp. 125134. https://doi.org/10.11634/232907811301328

Alm, J., Sanchez, I., de Juan, A. (1995). Economic and Noneconomic Factors in Tax Compliance. Kyklos, Vol. 48, No. 1, 1995, pp. 3-18. https://doi.org/10.1111/j.1467-6435.1995.tb02312.x

Bakija, J. (2011). Tax Rates and Labor Supply in OECD Countries. https://web.williams.edu/Economics/bakija/BakijaTaxRatesAndLaborSupplyInOECDCountries.pdf.

Beck, P.J., Davis, J. S., Jung, W. (1991). Experimental Evidence on Taxpayer Reporting Behaviour. The Accounting Review, Vol. 66, No. 3, 1991, pp. 535-558.

Chiarini, B., Marzano, E., Schneider, F. (2011). Tax rates and tax evasion: an empirical analysis of the long-run aspects in Italy. Eur J Law Econ (2013) 35:273-293. DOI 10.1007/s10657-011-9247-6.

Clotfelter, C. (1983). Tax Evasion and Tax Rates: An Analysis of Individual Returns. Review of Economics and Statistics, Vol. 65, No. 3, 1983, pp. 363-373. http://dx.doi.org/10.2307/1924181.

Crane, S., Nourzad, F. (1985). Time Value of Money and Income Tax Evasion under Risk-Averse Behavior: Theoretical Analysis and Empirical Evidence. Public Finance/ Finances Publiques, Vol. 40, No. 3, 1985, pp. 381-393.

Elizabeth, N. D., Kyalo, T., Maina., L. (2015). Influence of Tax Rates on Tax Compliance in The Informal sector in Kenya: Survey of Nyeri Town. Scholars Bulletin (A Multidisciplinary Bi-weekly Journal).; Vol1, Iss-6(Oct, 2015):157-162.

European Commision (2018). Study and Reports on the VAT Gap in the EU-28 Member States: 2018 Final Report.

TAXUD/2015/CC/131, Warsaw. https://ec.europa.eu/taxation customs/sites/taxation/files/2018 vat gap report en.pdf.

Fisman, R., Shang-Jin, W. (2001). Tax Rates and Tax Evasion: Evidence from "Missing Import" in China. NBER Working Paper N0. 8551. https://doi.org/10.3386/w8551

Freine-Seren, M.R., Panades, J. (2013). Do Higher Tax Encourage/Discourage Tax Compliance? Modern Economy, Vol.4 No.12(2013). DOl:10.4236/me.2013.412086.

Gashi, Kukaj, H. (2016). The Effect of taxes Rates on Fiscal Evasion and Avoidance. European Journal of Sustainable Development. Doi: 10.14207/ejsd.2016.v5n1p31.

Koncevičienè, I., Prievelis, M. (2012). Lietuvos mokesčiu sistemos efektyvumo vertinimas. Taikomoji ekonomika. Sisteminiai Tyrimai. : 2012.6/2 Doi: 10.7220/AESR.1822.7996.2012.6.2.1. 
Martišius, S. A., Kèdaitis, V. (2013). Statistinès analizès teorija ir metodai. Vilnius: Vilniaus universiteto leidykla.

Modugu, P. K., Eragbhe, E., \& Izedonmi, F. (2012). Government Accountability and Voluntary Tax Compliance in Nigeria. Research Journal of Finance and Accounting, 3(5), 69-76.

Pommerehne, W., Weck-Hannemann, H. (1996). Tax Rates, Tax Administration and Income Tax Evasion in Switzerland," Public Choice, Vol. 88, No. 1-2, 1996, pp. 161-170. http://dx.doi.org/10.1007/BF00130416.

Slemrod, J. (1985). An Empirical Test for Tax Evasion. Review of Economics and Statistics, Vol. 67, No. 2, 1985, pp. 232-238. http://dx.doi.org/10.2307/1924722. 